\title{
Teologiekroniek: Die relevansie van teologie in millennium drie
}

S J Joubert

(Universiteit van Pretoria)

\section{ABSTRACT}

\section{The relevance of theology in millennium three}

The ever growing emphasis on specialization in theological circles, coupled with constant pressure on theological researchers to come up with new theories, have, in many cases, turned theological study into an esoteric undertaking with no direct or indirect relevance to the church or society at large. In order to avoid the "museum of endangered species" that looms around the corner for a self-sufficient, highly specialized theology, theological research must, once again, take the church seriously as an eventual participant in the theological discourse. Theologians must learn to popularise their findings and to open new windows on God for people of the third millennium.

\section{INLEIDING}

Onlangs het ek die voorreg gehad om 'n kongres oor antieke huishoudings in die Grieks-Romeinse wêreld, en met name binne die vroeë Christendom, in die VSA by te woon. Van die wêreld se grootste kundiges op die terrein van antieke Romeinse huishoudings, asook op vroegChristelike- en Joodse families, het as sprekers by hierdie kongres opgetree. Aangesien ek verwag het dat belangstellende teoloë en historici van oral oor sou stroom om na hierdie kundiges te luister, het ek gesorg dat ek betyds registreer. Groot was my verbasing egter toe ek by die kongres opdaag en agterkom dat slegs sowat veertig mense, inlsuitende die sprekers, dit bywoon.

Hierdie grootskaalse afwesigheid van Noord-Amerikaanse, en ander, akademici by ' $\mathrm{n}$ kongres van buitengewone hoë akademiese gehalte het my laat wonder waar lê die fout. Is die kongres dalk swak gereklameer? $\mathrm{Na}$ my beste wete: nee! Was die kongres te duur? Nee, veral nie vir Amerikaners nie. Is die kongres op ' $n$ slegte tyd van die akademiese jaar aangebied? Na my beste wete: nee. Is allerlei esoteriese temas tydens die kongres behandel? Beslis nie.

Sou die swak bywoning van hierdie kongres dalk te wyte wees aan die feit dat dit ' $n$ byeenkoms van ' $n$ geslote groepie navorsers was wat vir ' $n$ geruime tyd reeds saamwerk en nie eintlik belangstel in die me- 
nings van ander, minder ingeligte, akademici nie? Moontlik. Soms het ek inderdaad die gevoel gekry dat hierdie gesogte akademici slegs mekaar as ernstige gesprekgenote beskou, ten koste van die menings van navorsers buite hulle groep. Maar ten spyte van hierdie akademiese warmbroeiery, het ek tog nie gevoel dat dit die enigste rede vir die swak opkoms by die kongres was nie. Miskien is die grootste rede hiervoor dalk te wyte aan, wat ek sou wou noem, die toenemende irrelevansie van gespesialiseerde teologiese navorsing binne ons samelewing in die breë.

\section{2 'N ONOORBRUGBARE KLOOF TUSSEN TEOLOGIE EN DIE KERK?}

Ons kan nie die feit wegredeneer dat teologiese opleiding wêreldwyd onder druk kom nie. Vanuit Europa verneem mens op ' $n$ gereelde basis van akademiese poste wat nie meer gevul word nie, en van teologiese fakulteite wat moet sluit of moer saamsmelt ten einde te oorleef. Getalle van voornemende teologiese studente is orals aan die taan, ook in Suid Afrika. Wat sou die redes hiervoor wees? Wel, te midde van faktore soos die toenemende wêreldwye sekularisasie en kwynende bevolkingsgetalle, sou ek ' $n$ klip in die bos wou gooi deur die fout ook voor die deur te lề van al ons professionele teoloë wat aan universiteite en teologiese kolleges klasgee. Ek sou dit as volg wou motiveer:

\subsection{Spesialisasie}

Vanweë die groot aantal teologiese publikasies wat jaarliks wêreldwyd in vakwetenskaplike tydskrifte en in monografieë die lig sien, raak dit vir teoloë onmoontlik om alle fasette van hulle onderskeie vakgebiede te beheer. Die enigste uitweg uit hierdie dilemma is spesialisasie. Teoloë konsentreer daarom dikwels op ' $n$ bepaalde teologiese tema binne hulle vakgebied waarop hulle indringend vir ' $n$ aantal jare, of straks vir die res van hulle lewe, navorsing doen. Daarom dat ' $n$ Nuwe-Testamentikus byvoorbeeld sy/haar hele lewe lank kan spesialiseer op een van die evangelies, of dat " $n$ dogmatikus vir jare slegs op een van die loci binne die dogmatiek kan fokus. Daar is soms egter ' $n$ hoë prys te betaal vir sodanige spesialisasie. Dit maak dat sommige teoloë uiteindelik baie van ' $n$ relatief klein deeltjie van die teologie af weet, maar weinig interesse of begrip het vir ander afdelings daarvan. Wanneer studente dan by sulke hoogs-gespesialiseerde teoloë aanland, verander hulle dikwels in klone van hulle leermeesters. Hulle sit met ander woorde maar net die tradisies van hulle eie teologiese ikone voort en verfyn selfs ook hulle leermeesters se werk. As gevolg van hierdie drang na spesialisasie word teologiese navorsing soms so gekompliseerd dat nog die breë kerklike publiek, nog teoloë in ander dissiplines, iets daarvan snap.

\subsection{Toenemende druk om nuwe inligting te ontsluit}

Daar is groot druk op teoloë wêreldwyd om nuwe kennisinhoude te ontsluit. Maar dit is nie meer so maklik om binne die internasionale teologiese arena iets nuut gesê te kry wat die aandag van ander teoloë sal trek nie. ' $n$ Kortpad vir sekere teoloë, veral binne die VSA, is om hulle na die openbare verhoog te wend waar hulle deur middel van allerlei omstrede teologiese debatte en stellings poog om die media se aandag te trek.

Hierdie nuwe "openbare" teologiese diskoers behels gewoonlik 'n kritiese bevraagtekening van basiese geloofs-aksiomas van die kerk wat uiteraard weer tot groot spanning by die breë kerklike publiek aanleiding gee. Die gevolg: negatiewe stereotipes van professionele teoloë binne die kerk duik deesdae al hoe meer op. By die gemiddelde lid van die kerklike publiek leef die verwagting immers nog dat teoloë die Bybel en die Christelike tradisie nie van vroeg tot laat aan ' $n$ radikale, destruktiewe kritiek, moet onderwerp nie.

Teoloë wat kies om in die openbaar as't ware teenoor die kerk stelling in te neem as "n "vyandige gespreksgenoot", en wat alles bevraagteken wat die kerk glo, saag aan die tak waarop hulleself ook sit. Want ten diepste bestaan alle teologiese instellings op grasie van die kerk - of professionele teoloë dit nou wil weet of nie! Sonder die kerk se oorkoepelende sambreel sal teologie as wetenskap kort voor lank in die sand van vergetelheid wegsyfer.

Natuurlik is dit nie teoloë se taak om links en regs stempels van goedkeuring te plaas op al die kerk se doen en late nie, veral nie op fundamentalistiese denkstromee binne die kerk nie. Die teologie moet altyd ' $n$ kritiese, uitdagende stem laat hoor; 'n profetiese stem wat die uitgediende tradisies en gebreke van die kerk en die samelewing ontmasker. Maar dan moet dit ten minste vanuit ' $n$ posisie van kritiese solidariteit met die kerk gedoen word, nie vanuit ' $n$ teenoorstaande, vyandige hoek nie. 'n Negatiewe ingesteldheid van die kant van die teologie jeens die kerk, en omgekeerd, is die spreekwoordelike dood in die pot. Hoekom sal studente enigsins nog lang ure in teologiese klaskamers kom verwyl net om te moet hoor alles in die Bybel staan op losse skroewe; dit is alles ' $n$ klomp halwe waarhede? Dan kan hulle mos vanuit die staanspoor sodanige teologiese studies systap en iets gaan bestudeer wat nie so onseker, of so vol uitgediende mites is nie.

\subsection{Nuwe teoretiese invalshoeke}

Teoloë maak dikwels van nuwe teoretiese invalshoeke vanuit ander akademiese dissiplines gebruik in hul bestudering van teologiese vraagstukke. Sommige van hierdie navorsingsmetodes vanuit studievelde soos die sosiale wetenskappe en die moderne taalkunde het inderdaad

ISSN 1609-9982 = VERBUM ET ECCLESIA Jrg 22 (1) 2001 
opwindende nuwe moontlikhede ontsluit vir die verstaan van die Bybel. Maar party teoloë maak soms gebruik van navorsingsmetodes wat nie werklik geskik is vir die bestudering van teologiese vraagstukke nie. Sekere teoretiese invalshoeke wat ontleen word vanuit ander akademiese dissiplines laat eenvoudig nie reg geskied aan die eie aard en inhoude van die teologie nie. Ek dink byvoorbeeld aan dekonstruksie-denke, wat in die tagtiger- en negentigerjare van die vorige eeu baie populêr was binne filosofiese en taalkundige kringe. Wanneer sodanige "vreemde" wetenskap-filosofiese invalshoeke konsekwent binne die teologie nagevolg word, lei dit tot ' $n$ relativering van geloof. ' $n$ Konsekwentrasionele benadering, wat steeds binne sommige akademiese sirkels byval vind, maak die deur eweneens toe in die gesig van diegene wat steeds in hulle geloof ruimte wil laat vir die metafisiese handelinge van God in die wêreld.

\subsection{Sosiale isolasie}

Soms is teoloë uit voeling met die realiteit(e) van die geloofsgemeenskappe rondom hulle. Nog erger: party teoloë beskou laasgenoemdes hoegenaamd nie eens as moontlike lesers van hulle navorsing, al is dit ook in een of ander gepopulariseerde vorm, nie. Teologie het op baie plekke in opsigself staande, onafhanklike groothede ontwikkel. Binne hierdie selfgenoegsame teologiese "glastorings" word allerlei esoteriese studies dikwels onderneem en komplekse debatte tussen die "ingewydes" gevoer.

' $n$ Selfgenoegsame teologie het op die lange duur geen toekoms nie. Dit word maklik deur diegene wat nie daarby betrokke is nie as irrelevant beleef. Sodanige akademiese aktiwiteite mag miskien vir die beoefenaars daarvan groot vreugde verskaf, maar as dit nie toeganklik of bruikbaar vir enigiemand anders daarbuite is nie, dan is dit vir baie buitestaanders niks anders as ' $n$ oefening in futiliteit nie.

\section{3}

\subsection{Teologie - 'n middel tot 'n doel}

Toenemende spesialisasie - hoe belangrik dit ook al mag wees - hou ' $n$ bedreiging vir die voortbestaan van die teologie in wanneer dit nie reg beoefen word nie. Indien teoloë nie daarin slaag om die bevindinge wat voortspruit uit hulle gespesialiseerde navorsing bevatlik te maak vir die samelewing en die kerk nie, dan loop teologie die gevaar om te verval in ' $n$ elitistiese, werklikheidsvreemde wetenskap met " $n$ eie "jargon", " $n$ vaktaal wat slegs deur ' $n$ klein groepie ingewydes verstaan word. Teoloë moet voortdurend daaraan herinner word dat teologiese refleksie ook in diens staan van geloofsgemeenskappe en die samelewing in die breë.
Teologisering mag nooit ' $n$ doel opsigself wees nie. Dit moet die middel tot ' $n$ doel wees. Gespesialiseerde teologiese navorsing moet eventueel bruikbaar gemaak word vir die breë omgewing. Daarom sal teoloë altyd weer uit hulle "akademiese gate" moet kruip ten einde diens aan die kerk te lewer. Hulle sal eenvoudig moet leer om hulle navorsing te populariseer en te veraktualiseer. So nie, sal die kerk en samelewing van millennium drie uiteindelik sonder die dienste van professionele teoloë voortgaan.

Ons moet tog nie die fout makk om te dink die kerk sal in duie stort sonder die akademiese insette van die kant van teoloë nie. Van die mees innoverende nuwe ontwikkelings vind in elk geval tans in plaaslike gemeentes regoor die wêreld plaas waar leraars en gelowiges kreatief op die nuwe uitdagings van die dag inspeel. Verantwoordelike homiletiese en liturgiese vernuwing is byvoorbeeld aan die orde van die dag in vele plaaslike kerke. Sendingwerk binne lokale kerkverband beleef ook die grootste opbloei in baie jare. Net so neem die studie van die Bybel by Bybelskole op voetsoolvlak hand oor hand toe. Lidmate is lank nie meer direk van professionele Bybelwetenskaplikes afhanklik vir die verstaan van die Bybel nie. Indien teoloë nie ernstig kennis neem van hierdie toenemende "selfstandigwording" van plaaslike gemeentes, en daadwerklik begin om diens aan hulle te lewer nie, sal teologie al hoe meer uit pas raak met die religieuse uitdagings van ons dag.

\subsection{Relevansie is die wagwoord}

Ons leef in ' $n$ snel veranderende samelewing. Die grootste tegnologiese rewolusie in menseheugenis speel dag vir dag rondom ons af. Kenmerkend van hierdie tegnologiese ontploffing is die vinnige verspreiding en ontsluiting van kennis deur middel van tegnologiese media soos die internet, CDs en DWD-tegnologie. Eie aan hierdie tegnologiese opbloei is die onmiddellike beskikbaarheid van kennis, tesame met ' $n$ gepaardgaande "kleiner-wording" van die wêreld. 'n Jaar of twee gelede is daar nog gepraat van die wêreld as "n "global village." Deesdae praat mense soos Tom Peters, wat alomweë beskou word as een van die leidende besigheids-gurus in die wêreld, straks al van die wêreld as " $n$ "global mall".

Binne hierdie nuwe tegnologiese wêreld wat mense elke dag in die gesig tref, is relevansie, nee: direkte relevansie, die nuwe wagwoord. Teoloë mag dit goedskiks ignoreer; hulle mag maak of dit hulle nie direk raak nie. Maar dit sou dwaas wees. Want die tegnologiese rewolusie raak die ganse wêreld. Sonder dat ons dit agterkom, is ons almal "slagoffers" van die sindroom van direkte relevansie, wat een van die "neweprodukte" van die tegnologiese ontwikkeling is. Die sindroom van direkte relevansie lei dikwels tot ' $n$ verkorte aandagspan, tot ' $n$ gedurige soeke 
na nuwe sensoriese stimulasie by die "slagoffers" daarvan. En dit het natuurlik weer allerlei implikasies vir indiwidue se ervarings en belewenisse van die realiteit. Ten minste vra hierdie nuwe sug na relevansie ' $n$ meer toeganklike wetenskap wat inligting baie vinniger ontsluit en gouer bevatlik maak as ooit vantevore. Die luukse van ses tot tien jaar se akademiese studie, wat nie te veel nuwe kennis ontsluit wat prakties bruikbaar is nie, se dae is getel.

Teologie durf nie die impak van tegnologiese ontwikkelings op die derde millennium mens ignoreer nie. Dan gaan so 'n teologie in een of ander hoekie van eensames sterf. Niemand sal dit eens agterkom nie. Die enigste hoop vir teoloë is om teologiese navorsing te doen wat binne die huidige tydsgewrig aktueel, uitdagend en ook meer diensgerig is. Hierdie navorsing sal ook veel meer dialogies moet wees, meer deelnemend van aard. Ten minste sal teoloë hulle reg tot spesialisasie moet "verdien" deur die kuns te bemeester om hulle teologiese navorsing onder andere in makliker verteerbare vorms beskikbaar te stel. Maar dan moet hulle dit ook doen vanuit ' $n$ posisie van kritiese solidariteit met die geloofsgemeenskappe rondom hulle. Teoloë sal weer spore van hoop moet trap waarin die kerk hulle kan navolg.

\section{SLOT OPMERKINGS}

Teologie staan ook in diens van die kerk in die breë. Sonder ' $n$ ingesteldheid van dienslewering teenoor kerklike vennote verval teologie gou in hubris, in ' $\mathrm{n}$ hoogmoedige beterweterigheid. Wanneer teoloë hulle navorsing bedryf met ten minste een oog gerig op die geloofsgemeenskappe rondom hulle, is daar regtig sprake van 'n gesonde bondgenootskap tussen kerk en teologie. Teoloë moet die kerk deurentyd help om nuwe vergesigte op God te ontsluit wat gelowiges weer met hoop kan laat leef. Professionele teoloë moet die kerk ook begelei om nuut en kreatief oor God na te dink.

Of teoloë dit wil weet of nie, die teologie soos wat dit tans in sommige kringe bedryf word, is besig om irrelevant, selfs esoteries, te raak. Aan die ander kant groei dinamiese kerke wêreldwyd met rasseskrede. Leraars besef toenemend dat hulle ook teoloë in eie reg is. Nog meer: hulle besef dat hulle eie teologie(ë) in die praktyk haalbaar moet wees, omdat hulle in elk geval nie te veel kan doen met dit wat sommige professionele teoloë hulle aanbied nie.

Teologie in millennium drie staar ' $n$ paar kritiese uitdagings in die gesig. Die keuses wat teoloë in hierdie verband gaan maak, sal bepaal of teologie steeds as ' $n$ relevante, dinamiese wetenskaplik sal bly voortbestaan, en of dit eventueel gedegradeer gaan word na ' $n$ onderafdeling van algemene godsdiensstudies aan tersiêre instellings. Indien teologiese navorsers meen hulle werk is om akademiese post mortems op die dooie tekste van uitgestorwe godsdienstige groepe te doen, dan is die museum vir bedreigde spesies binnekort die teologie se voorland. Maar as teoloë aanvaar dat die Christendom steeds ' $n$ lewende, lewenskragtige godsdiens is wat, ten spyte van die verweer van die tyd, steeds gedy, dan sal hulle konstruktiewe akademiese bydraes lewer tot die nadenke oor God. Dan sal hulle aktief meewerk tot nuwe, dinamiese vergestaltings van geloof in millennium drie. 